\title{
Modulation of uPA, MMPs and their inhibitors by a novel nutrient mixture in human glioblastoma cell lines
}

\author{
M. WAHEED ROOMI, TATIANA KALINOVSKY, ALEKSANDRA NIEDZWIECKI and MATTHIAS RATH \\ Dr Rath Research Institute, Santa Clara, CA 95050, USA
}

Received March 4, 2014; Accepted May 2, 2014

DOI: $10.3892 / \mathrm{ijo} .2014 .2465$

\begin{abstract}
Brain tumors are highly aggressive tumors that are characterized by high levels of matrix metalloproteinase (MMP)-2 and -9 secretions that degrade the extracellular matrix (ECM) and basement membrane, allowing cancer cells to spread to distal organs. Proteases play a key role in tumor cell invasion and metastasis by digesting the basement membrane and ECM components. Strong clinical and experimental evidence demonstrates association of elevated levels of urokinase plasminogen activators (UPA) and MMPs with cancer progression, metastasis and shortened patient survival. MMP activities are regulated by specific tissue inhibitors of metalloproteinases (TIMPs). Our main objective was to study the effect of a nutrient mixture (NM) on the activity of uPA, MMPs and TIMPs in various human gliomas. Human glioblastoma (LN-18, T-98G and A-172) cell lines (ATCC) were cultured in their respective media and treated at confluence with NM at 0, 50, 100, 250, 500 and $1000 \mu \mathrm{g} / \mathrm{ml}$. Analysis of uPA activity was carried out by fibrin zymography, MMPs by gelatinase zymography and TIMPs by reverse zymography. Glioblastoma cell lines LN-18 and T-98G expressed uPA, which was inhibited by NM in a dose-dependent manner. However, no bands corresponding to UPA were detected for the A-172 cell line. On gelatinase zymography, all three cell lines showed bands corresponding to MMP-2 and LN-18 and T-98G showed PMA (100 ng/ml)-induced MMP-9. NM inhibited their expression in a dose-dependent manner. Activity of TIMP-2 was upregulated by NM in all glioma cell lines in a dose-dependent manner. Analysis revealed a positive correlation between UPA and MMP-2 and a negative correlation between uPA/MMPs and TIMP-2. These findings suggest the therapeutic potential of NM in the treatment of gliomas.
\end{abstract}

Correspondence to: Dr Aleksandra Niedzwiecki, Dr Rath Research Institute, 1260 Memorex Drive, Santa Clara, CA 95050, USA

E-mail: author@drrath.com

Key words: glioblastoma LN-18, T-98G and A-172, urokinase plasminogen activator, matrix metalloproteinase-2 and -9 , tissue inhibitor of metalloproteinase-2, PMA, nutrient mixture

\section{Introduction}

Approximately 23,130 new cases and 14,080 deaths from brain and nervous system tumors were estimated in the United States for adults in 2013 (1). Brain cancer (mainly gliomas and medulloblastomas) is the second (after leukemia) leading cause of cancer death in children aged under 15, accounting for one third of all cancer deaths in this age group (2). In 2013, approximately 4,300 children younger than the age of 20 were expected to be diagnosed with primary brain tumors, of whom 3,050 were under the age of 15 (2). Gliomas, a broad term which includes all tumors arising from the supportive tissue of the brain, represent $30 \%$ of all brain tumors and $80 \%$ of all malignant tumors (2). Glioblastomas represent $17 \%$ of all primary brain tumors and $54 \%$ of all gliomas (2). Some pediatric brain tumors, such as brain stem gliomas and pontine gliomas, are terminal upon diagnosis and no new protocols have been developed in 30 years (3).

Though most brain tumors tend not to metastasize to distant areas outside the brain and/or spinal cord, they do tend to recur locally or spread to other areas of the CNS. Tumor cell invasion depends upon degradation of the extracellular matrix (ECM), which, when intact, acts as a barrier to block cancer cell invasion. The ECM is composed of collagen, proteoglycans, fibronectin, laminin and other glycoproteins (4-6). Two families of proteases, the matrix metalloproteinases (MMPs) and urokinase plasminogen activators (UPA) are involved in tumor invasion and metastasis. Numerous clinical and experimental studies have demonstrated that elevated levels of uPA and MMPs are associated with tumor growth, cancer progression, metastasis and shortened survival in patients (7).

MMPs, especially MMP-2 and MMP-9 play key roles in tumor cell invasion and metastasis due to their ability to degrade type IV collagen, a major component of basement membranes $(6,8,9)$. MMP-2 and -9 are secreted as inactive pro-enzymes in their latent zymogenic form, and activated by other MMPs or proteases. Proteolytic activities of MMP-2 and MMP-9 are inhibited by specific inhibitors, tissue inhibitors of metalloproteinases (TIMPs). Thus, a critical determinant of net proteolytic degradation is the balance between MMP and TIMP levels. Clinical studies note the association of MMP expression with progression of brain tumors $(10,11)$. Jäälinoiä et al found that MMP-2 expression correlated with survival in malignant brain tumors (10). The mean survival of patients with an MMP-2 negative tumor was 36 months, contrasted with 7-14 months 
in patients with an MMP-2 positive tumor (10). When Smith et al examined urine, cerebrospinal fluid and tissue specimens immunohistochemicallyfrom patients with brain tumors, they noted that brain tumor presence was significantly correlated with elevated MMP-2 and MMP-9 levels and resection of tumors correlated with decreased levels of MMPs (11).

The serine protease uPA converts plasminogen to plasmin, which is capable of promoting tumor growth and angiogenesis, degrading the ECM and basement membrane and activating pro-MMPs (12). Components of the uPA system such as uPA, plasminogen activator inhibitor-1 (PAI-1), and urokinase-type plasminogen activator receptor (u-PAR) are overexpressed in a variety of cancer types, most notably in breast cancer (13), but also in brain tumors (14), and correlate with cancer progression, metastasis and poor prognosis. Bindal et al reported that high levels of uPA were found in malignant glioma and metastatic tumors whereas normal levels of uPA were found in low-grade gliomas (14). Furthermore, patients with no detectable tissue plasminogen activator (tPA) activity correlated with histologically malignant brain tumors, aggressive characteristics and shorter survival (14). Thus the uPA system represents a potential target for anticancer strategies.

Rath and Pauling (15) proposed using nutrients such as lysine and ascorbic acid to target plasmin-mediated connective tissue degradation as a universal approach to tumor growth and expansion. Binding to plasminogen active sites, lysine blocks plasminogen activation into plasmin by tPA. Thus it modulates the plasmin-induced MMP activation cascade (16). Subsequent studies confirmed this approach and led to identifying a novel formulation composed of lysine, ascorbic acid, proline and green tea extract and other micronutrients (NM), which has shown significant anticancer activity against a large number ( 40) of cancer cell lines, blocking cancer growth, tissue invasion and MMP expression both in vitro and in vivo (17). In this study, we focused on the modulating effect of NM on the activities of MMP-2 and -9, TIMPs and UPA in human glioblastoma cell lines LN-18, T98G and A-172.

\section{Materials and methods}

Materials. Human glioblastoma cell lines LN-18, T-98G and A-172, along with their culture media were obtained from ATCC. Antibiotics, penicillin and fetal bovine serum (FBS), were obtained from Gibco (BRL, Long Island, NY). Twenty-four well tissue culture plates were obtained from Costar (Cambrdige, MA). Gelatinase zymography was performed in $10 \%$ Novex precast SDS polyacrylamide gel (Invitrogen, Inc.) with $0.1 \%$ gelatin in non-reducing conditions. The nutrient mixture (NM), prepared by VitaTech (Hayward, CA) was composed of the following ingredients in the relative amounts indicated: Vitamin $\mathrm{C}$ (as ascorbic acid and as $\mathrm{Mg}, \mathrm{Ca}$ and palmitate ascorbate) $700 \mathrm{mg}$; L-lysine $1000 \mathrm{mg}$; L-proline $750 \mathrm{mg}$; L-arginine $500 \mathrm{mg}$; $\mathrm{N}$-acetyl cysteine $200 \mathrm{mg}$; standardized green tea extract $(80 \%$ polyphenol) $1000 \mathrm{mg}$; selenium $30 \mu \mathrm{g}$; copper $2 \mathrm{mg}$; manganese $1 \mathrm{mg}$. All other reagents used were of high quality and were obtained from Sigma, unless otherwise indicated.

Cell cultures. The glioma cell lines were grown in DME, supplemented with $10 \% \mathrm{FBS}$, penicillin $(100 \mathrm{U} / \mathrm{ml})$ and streptomycin $(100 \mu \mathrm{g} / \mathrm{ml})$ in 24 -well tissue culture plates. The cells were plated at a density of $1 \times 10^{5}$ cells $/ \mathrm{ml}$ and grown to confluency in a humidified atmosphere at $5 \% \mathrm{CO}_{2}$ at $37^{\circ} \mathrm{C}$. Serum-supplemented media were removed and the cell monolayer was washed once with PBS with the recommended serum-free media. The cells were treated with the nutrient mixture, dissolved in media and tested at 0, 50, 100, 250, 500 and $1000 \mu \mathrm{g} / \mathrm{ml}$ in triplicate at each dose for uPA and TIMP-2 studies. For MMP analysis, cells were treated with NM at 0 , $10,50,100,500$ and $1000 \mu \mathrm{g} / \mathrm{ml}$. Parallel sets of cultures were treated with PMA (100 ng/ml) for induction of MMP-9. Control and PMA treatments were done in triplicates. The plates were then returned to the incubator. The conditioned media were collected separately, pooled and centrifuged at $40^{\circ} \mathrm{C}$ for $10 \mathrm{~min}$ at $3000 \mathrm{rpm}$ to remove cells and cell debris. The supernatant was collected and used to assess for uPA activity (by fibrin zymography on $10 \%$ SDS-PAGE gels containing fibrinogen and plasminogen), MMP-2 and -9 (by gelatinase zymography) and TIMPs (by reverse zymography).

Fibrin zymography. Fibrin zymography was used to analyze uPA activity on $10 \%$ SDS-PAGE gels containing fibrinogen $(5.5 \mathrm{mg} / \mathrm{ml})$ and plasminogen $(50 \mu \mathrm{g} / \mathrm{ml})$. After electrophoresis, the gels were washed twice with $2.5 \%$ Triton $\mathrm{X}-100$ for $30 \mathrm{~min}$. The gels were then incubated overnight at $37^{\circ} \mathrm{C}$ with $0.1 \%$ glycine buffer $\mathrm{pH} 7.5$ and then stained with $0.5 \%$ Coomassie Brilliant Blue R250 and destained. Electrophoresis of uPA and tPA were conducted for comparison. Fibrin zymograms were scanned using CanoScan 9950F Canon Scanner.

Gelatinase zymography. Gelatinase zymography was performed in $10 \%$ Novex pre-cast SDS polyacrylamide gel (Invitrogen Corp.) in the presence of $0.1 \%$ gelatin under non-reducing conditions. Culture media $(20 \mu \mathrm{l})$ were mixed with sample buffer and loaded for SDS-PAGE with Tris glycine SDS buffer as suggested by the manufacturer (Novex). Samples were not boiled before electrophoresis. Following electrophoresis the gels were washed twice in $2.5 \%$ Triton X-100 for $30 \mathrm{~min}$ at room temperature to remove SDS. The gels were then incubated at $37^{\circ} \mathrm{C}$ overnight in substrate buffer containing $50 \mathrm{mM}$ Tris- $\mathrm{HCl}$ and $10 \mathrm{mM} \mathrm{CaCl}_{2}$ at $\mathrm{pH} 8.0$ and stained with $0.5 \%$ Coomassie blue R250 in 50\% methanol and $10 \%$ glacial acetic acid for $30 \mathrm{~min}$ and destained. Upon renaturation of the enzyme, the gelatinases digest the gelatin in the gel and give clear bands against an intensely stained background. Protein standards were run concurrently and approximate molecular weights were determined by plotting the relative mobilities of known proteins.

Reverse zymography. TIMPs were analyzed by reverse zymography on $15 \%$ SDS gels containing serum-free conditioned medium from cells. After electrophoresis the gels were washed twice with $2.5 \%$ Triton-X for $30 \mathrm{~min}$ at room temperature to remove SDS. The gels were then incubated at $37^{\circ} \mathrm{C}$ overnight in $50 \mathrm{mM}$ Tris- $\mathrm{HCl}$ and $10 \mathrm{mM} \mathrm{CaCl}_{2}$ at $\mathrm{pH} 7.6$ and stained with $0.5 \%$ Coomassie blue R25, destained and scanned.

Scanning of gelatinase, reverse and fibrin zymograms. Gelatinase, reverse and fibrin zymograms were scanned using CanoScan 9950F Canon scanner at 300 dpi. The intensity of the bands was evaluated using the pixel-based densitometer 
Table I. Overview of MMP-2 and -9, uPA and TIMP-2 expression of glioma cell lines.

\begin{tabular}{lccccc}
\hline Cancer cell line & MMP-2 & $\begin{array}{c}\text { MMP-9 } \\
\text { with PMA }\end{array}$ & uPA & TIMP-2 \\
\hline Glioblastoma LN-18 & + & + & + & + \\
Glioblastoma T-98G & + & + & + & + \\
Glioblastoma A-172 & + & - & - & + \\
\hline
\end{tabular}

program Un-Scan-It, Version 5.1, 32-bit, by Silk Scientific Corp. (P.O. Box 533, Orem, UT, USA), at a resolution of 1 Scanner Unit (1/100 of an inch for an image that was scanned at $100 \mathrm{dpi}$ ). The pixel densitometer calculates the optical density of each pixel (values 0-255) using the darkly stained background of the gel as a pixel value of 0 . A logarithmic optical density scale was used since the optical density of the film and gels is logarithmically proportional to the concentration. The pixel densitometer sums the optical density of each pixel to give the band density.

Statistical analysis. Pearson's correlation coefficient was determined between NM effect on the mean MMP-2, uPA and TIMP-2 expression of glioma cell lines using MedCalc Software (Mariakerke, Belgium).

\section{Results}

Table I provides an overview of the activity of uPA, MMP and TIMP-2 in the tested glioma cell lines.

Effect of NM on UPA activity in human glioma cell lines. Activity of uPA was detected in glioma LN-18 and T-98G cell lines. LN-18 and T-98G showed one band corresponding to subunit 1 at $55 \mathrm{kDa}$. However, no bands corresponding to uPA were detected for cell line A-172. NM exerted dose response inhibition with virtual block of uPA activity of subunit 1 in $\mathrm{LN}-18$ at $250 \mu \mathrm{g} / \mathrm{ml}$ (linear trend $\mathrm{R}^{2}=0.842$ ) and in $\mathrm{T}-98 \mathrm{G}$ at $1000 \mu \mathrm{g} / \mathrm{ml}$ (linear trend $\mathrm{R}^{2}=0.713$ ). See Fig. 1 for respective fibrin zymograms and densitometry analyses.

Effect of NM on MMP-2 and MMP-9 expression in the glioma cell line LN-18. On gelatinase zymography, LN-18 cells demonstrated expression of MMP-2, but no MMP-9 expression. MMP-2 was inhibited by NM in a dose-dependent fashion with virtual total inhibition at $500 \mu \mathrm{g} / \mathrm{ml}$ (linear trend $\left.\mathrm{R}^{2}=0.677\right)$. PMA (100 ng/ml) treatment induced MMP-9 expression by LN-18 cells; NM inhibited MMP-2 and MMP-9 in a dose-dependent manner with total block of MMP-2 at $100 \mu \mathrm{g} / \mathrm{ml}$ (linear trend $\mathrm{R}^{2}=0.734$ ) and total block of MMP-9 at $50 \mu \mathrm{g} / \mathrm{ml}$ (linear trend $\mathrm{R}^{2}=0.553$ ). See Fig. 2 for gelatinase zymograms and densitometry analyses.

Effect of NM on MMP-2 and MMP-9 expression in the glioma cell line T-98G. On gelatinase zymography, T-98G cells demonstrated expression of MMP-2, but no MMP-9 expression. MMP-2 was inhibited by NM in a dose-dependent fashion with virtual total inhibition at $1000 \mu \mathrm{g} / \mathrm{ml}$ (linear trend $\left.\mathrm{R}^{2}=0.951\right)$. PMA $(100 \mathrm{ng} / \mathrm{ml})$ treatment induced MMP-9 expression by T-98G cells; NM inhibited MMP-2 and MMP-9 in a dose-dependent manner with total block of MMP-2 at $1000 \mu \mathrm{g} / \mathrm{ml}$ (linear trend $\mathrm{R}^{2}=0.863$ ) and total block of MMP-9 at $100 \mu \mathrm{g} / \mathrm{ml}$ (linear trend $\mathrm{R}^{2}=0.734$ ). See Fig. 3 for gelatinase zymograms and densitometry analyses.

Effect of NM on MMP-2 and MMP-9 expression in the glioma cell line A-172. On gelatinase zymography, A-172 cells demonstrated expression of MMP-2, but no MMP-9 expression even
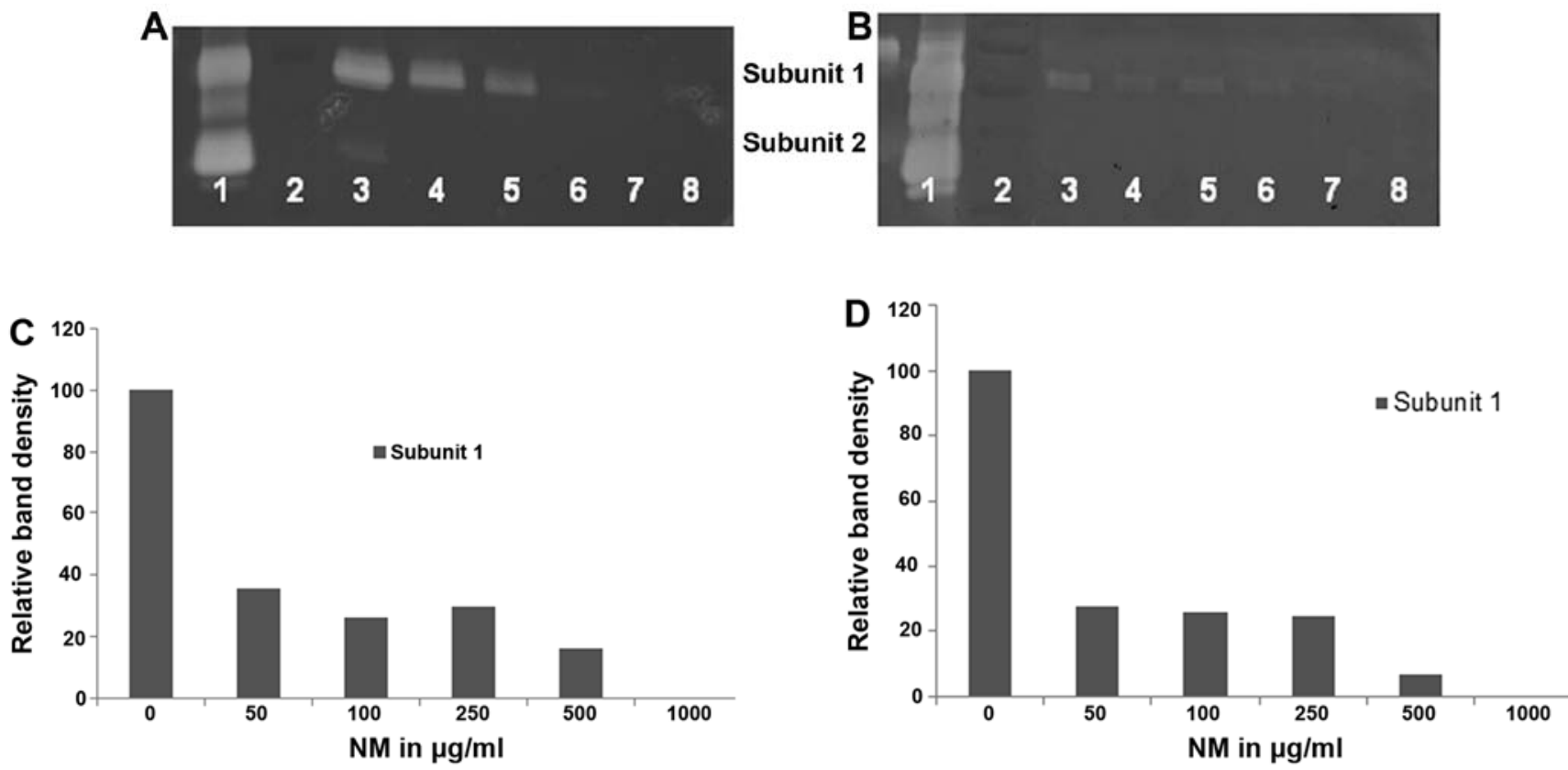

Figure 1. Effect of NM on uPA activity in glioma LN-18 and T-98G cell lines. Fibrin zymograms of LN-18 (A) and T-98G (B) uPA expression. 1, uPA; 2, markers; 3, control; 4-8 NM, 50, 100, 250, 500 and $1000 \mu \mathrm{g} / \mathrm{ml}$. Densitometric analyses of LN-18 (C) and T-98G (D) uPA expression. 

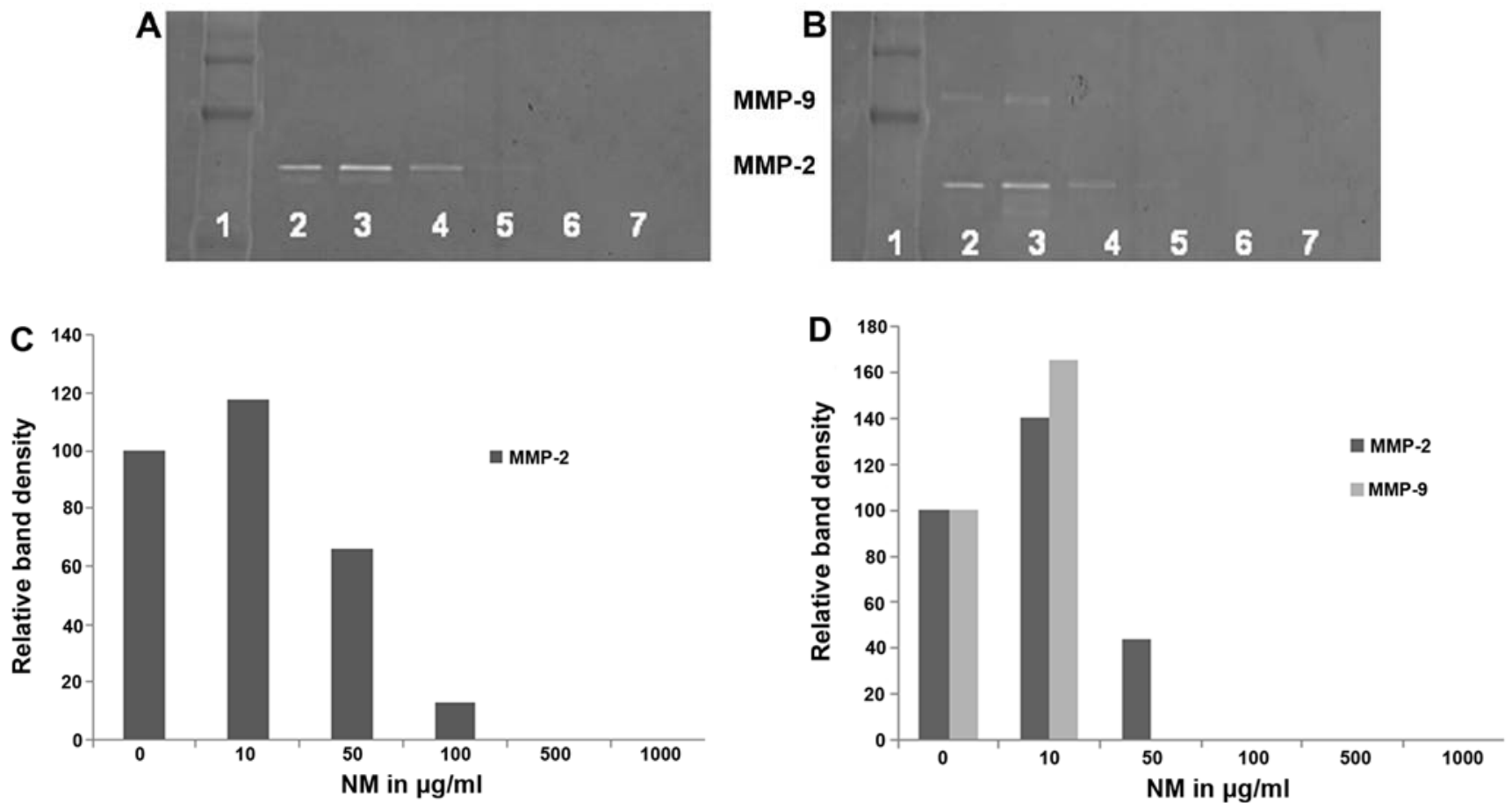

Figure 2. Effect of NM on MMP-2 and -9 secretion in glioma LN-18. Gelatinase zymograms of normal LN-18 (A) and PMA (100 ng/ml)-treated LN-18 (B) MMP-2 and MMP-9 expression. 1, markers; 2, control; 3-7 NM, 10, 50, 100, 500 and $1000 \mu \mathrm{g} / \mathrm{ml}$. Densitometric analyses of normal (C) and PMA-treated (D) LN-18 MMP-2 and -9 secretion.
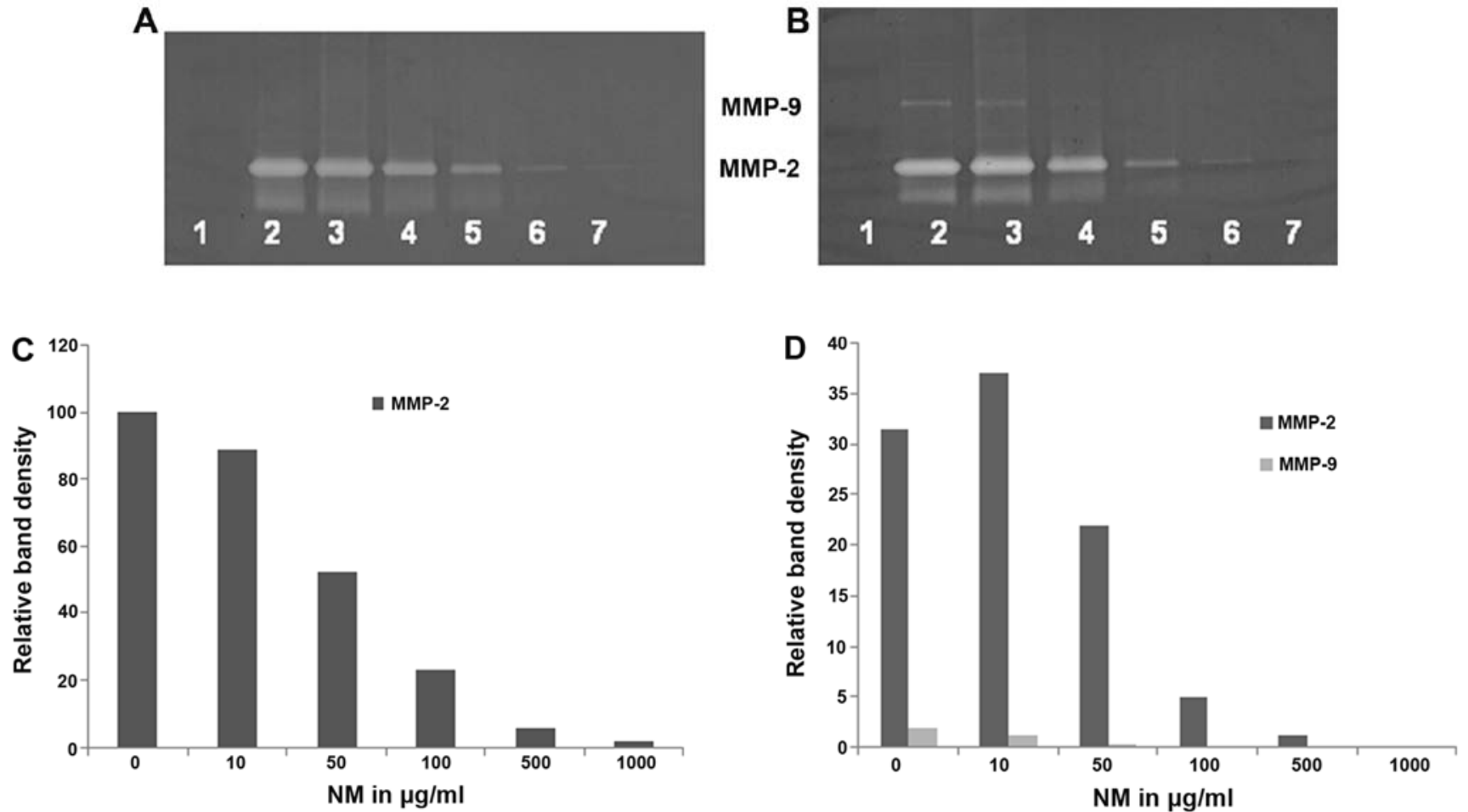

Figure 3. Effect of NM on MMP-2 and -9 secretion in glioma T-98G. Gelatinase zymograms of normal T-98G (A) and PMA (100 ng/ml)-treated T-98G (B) MMP-2 and MMP-9 expression. 1, markers; 2, control, 3-7 NM, 10, 50, 100, 500 and $1000 \mu \mathrm{g} / \mathrm{ml}$. Densitometric analyses of normal (C) and PMA-treated (D) T-98G MMP-2 and -9 secretion.

with PMA (100 ng/ml) treatment. MMP-2 was inhibited by NM dose-dependently with virtual total inhibition at
$1000 \mu \mathrm{g} / \mathrm{ml}$ (linear trend $\mathrm{R}^{2}=0.834$ ). See Fig. 4 for gelatinase zymogram and densitometry analysis. 
A

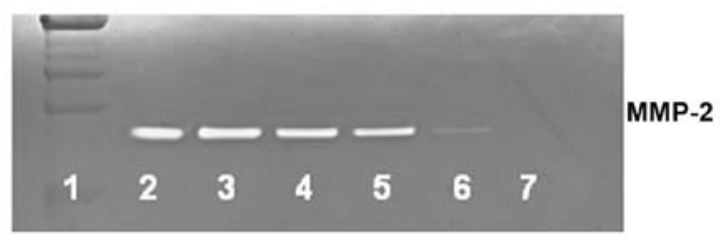

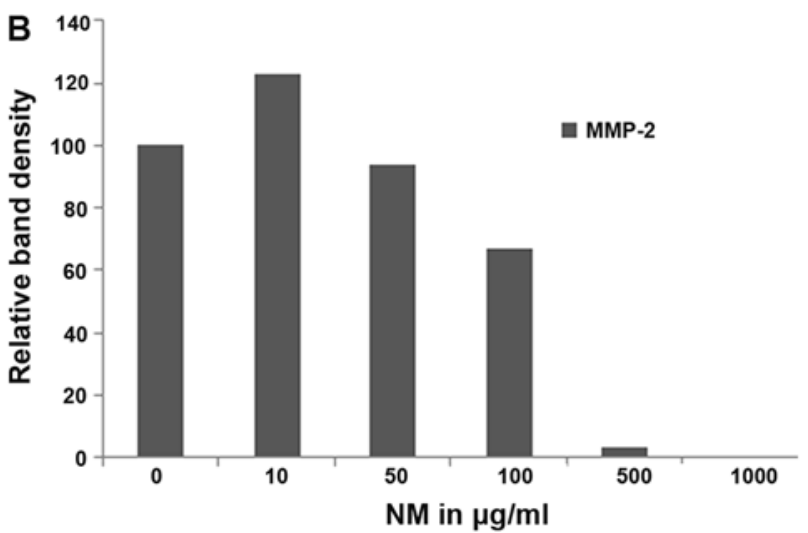

Figure 4. Effect of NM on MMP-2 and -9 secretion in glioma A-172. Gelatinase zymogram of normal A-172 (A) MMP-2 and MMP-9 expression. 1, markers; 2, control; 3-7 NM, 10, 50, 100, 500 and $1000 \mu \mathrm{g} / \mathrm{ml}$. Densitometric analysis of normal (B) A-172 MMP-2 and -9 secretion.

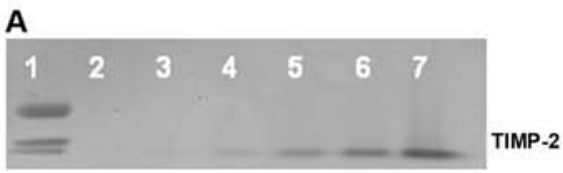

B

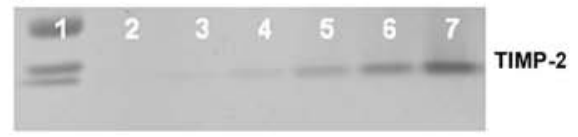

C

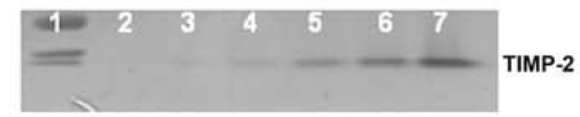

D
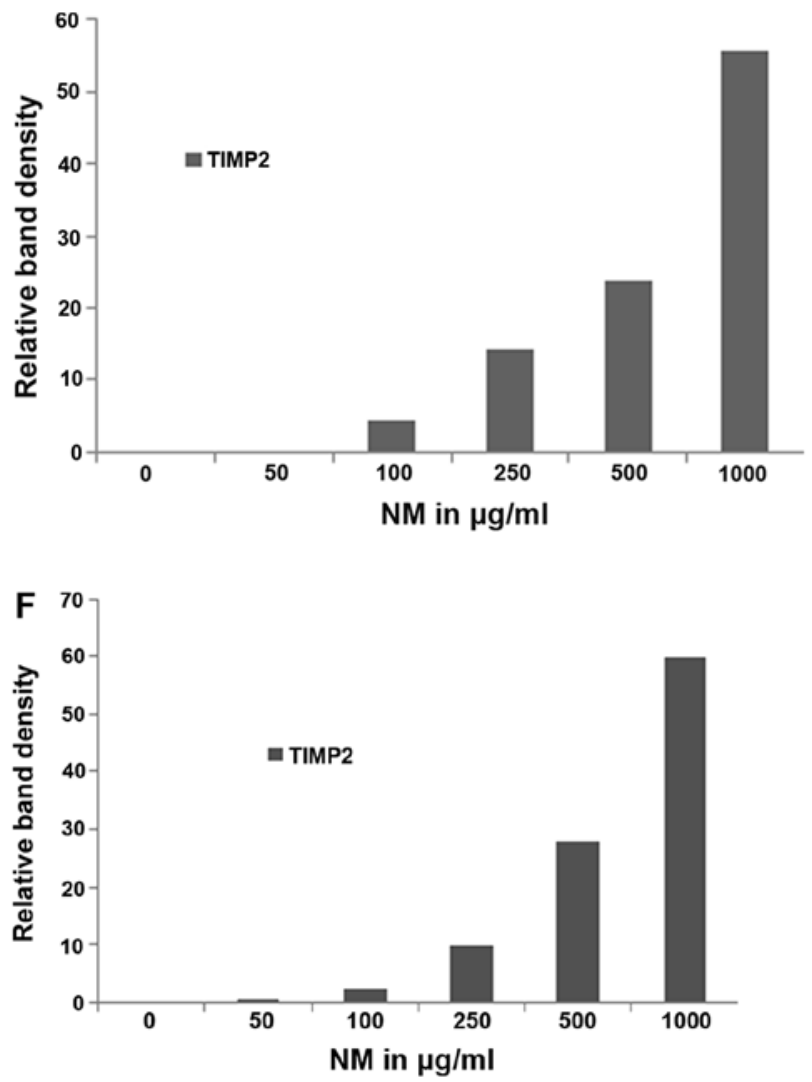

Effect of NM on TIMP activity in glioma cell lines. Reverse zymography revealed upregulation of TIMP-2 activity with NM treatment in all glioma cell lines in a dose-dependent manner. Minimum activity was expressed at 50 and maximum at $1000 \mu \mathrm{g} / \mathrm{ml} \mathrm{NM}$. See Fig. 5 for reverse zymograms and densitometry analyses.

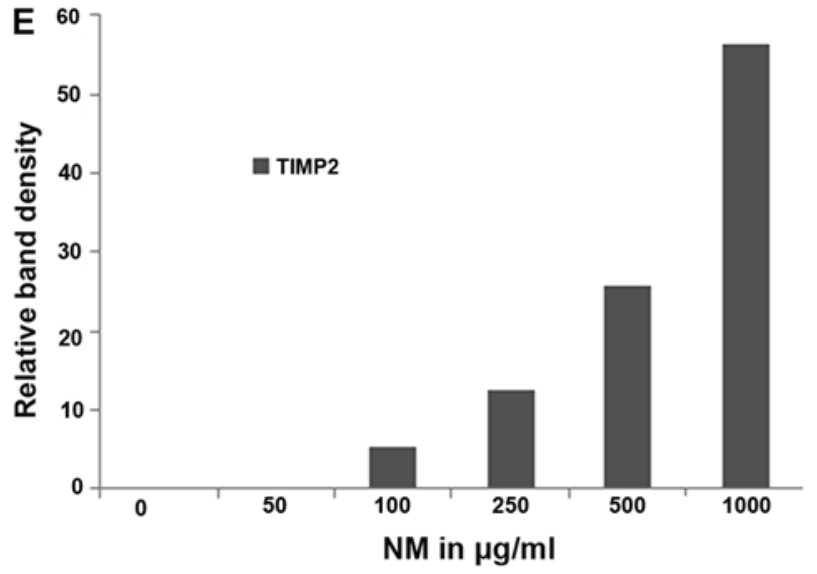

Figure 5. Effect of NM on TIMP-2 activity in glioma LN-18, T-98G and A-172 cell lines. Reverse zymograms of LN-18 (A), T-98G (B) and A-172 (C) TIMP-2 expression. 1, markers; 2, control: 3-7 NM, 50, 100, 250, 500 and $1000 \mu \mathrm{g} / \mathrm{ml}$. Densitometric analyses of LN-18 (D), T-98G (E) and A-172 (F) TIMP-2 expression.
Correlation between expression of $u P A, T I M P-2$ and MMP. Analysis revealed a positive correlation between expression of uPA and MMP-2 of NM-treated glioma cell lines LN-18 and T-98G, as shown in Table II. Fig. 6A shows the correlation graph for LN-18 uPA and MMP-2 with a correlation coefficient $r=0.504$. Negative correlations were found between the 
Table II. Correlation between effects of NM on glioma cells by uPA, MMPs and TIMPs.

\begin{tabular}{lccc}
\hline Cell line & $\begin{array}{c}\text { uPA and } \\
\text { MMP-2 }\end{array}$ & $\begin{array}{c}\text { MMP-2 and } \\
\text { TIMP2 }\end{array}$ & $\begin{array}{c}\text { uPA and } \\
\text { TIMP2 }\end{array}$ \\
\hline Glioblastoma LN-18 & $\mathrm{r}=0.504$ & $\mathrm{r}=-0.842$ & $\mathrm{r}=-0.679$ \\
Glioblastoma T-98G & $\mathrm{r}=0.415$ & $\mathrm{r}=-0.871$ & $\mathrm{r}=-0.635$ \\
Glioblastoma A-172 & N/A & $\mathrm{r}=-0.893$ & N/A \\
\hline
\end{tabular}

expression of MMP-2 and TIMP-2 in all three glioma cell lines treated with NM as shown in Table II. The correlation $(\mathrm{r}=-0.842)$ between MMP- 2 and TIMP- 2 is shown for $\mathrm{LN}-18$ in Fig. 6B. Negative correlations were found between expressions of TIMP-2 and uPA in glioma cell lines LN-18 and T-98G, as shown in Table II. Fig. 6C shows the correlation graph for LN-18 TIMP2 and uPA.

\section{Discussion}

Tumor cell invasion requires the critical steps of cell attachment, degradation of the ECM and migration through the disrupted matrix. The two families of proteases, matrix metalloproteinases and urokinase plasminogen activators play key roles in tumor cell invasion. Experimental studies have demonstrated the role of urokinase plasminogen, especially cell surface uPA, as an initiator of ECM proteolysis and associated tumor cell invasion (16). The protease uPA converts plasminogen to plasmin, which is capable of promoting tumor growth and angiogenesis, degrading the ECM and basement membrane and activating pro-MMPs (12). Overexpression of UPA in brain tumor patients has been correlated with cancer progression, metastasis and poor prognosis (14). Matrix metalloproteinases, especially MMP-2 and MMP-9, play pivotal roles in tumor cell invasion and metastasis due to their ability to degrade type IV collagen, a major component of basement membranes. Overproduction of MMPs, especially MMP-2 and -9 have been shown to be associated with a more aggressive behavior of brain tumors $(10,11)$.

Our study demonstrated that the specific mixture of nutrients tested significantly inhibited uPA secretion in glioblastoma cell lines LN-18 and T-98G. (Glioma cell line A-172 was not found to secrete uPA in this study). Furthermore, the NM demonstrated dose-dependent decrease in MMP secretion and increase in TIMP-2 secretion by all glioma cell lines. As expected, a significant positive correlation was found between the secretion of UPA and MMP-2 and a significant negative correlation between UPA and TIMP-2 by NM treatment of glioma cell lines LN-18 and T-98G. In addition a significant negative correlation was found between MMP-2 and TIMP-2 secretion by NM treatment of all three glioma cell lines. Furthermore, a previous study demonstrated a significant negative correlation ( $r=-0.953)$ between NM inhibition of Matrigel invasion and NM modulation of the MMP-2 activity of glioma cell line A-172 (18).

In contrast to the associated toxicity and limited efficacy of standard cancer chemotherapy and radiation therapy, the efficacy and safety of dietary and botanical natural compounds in
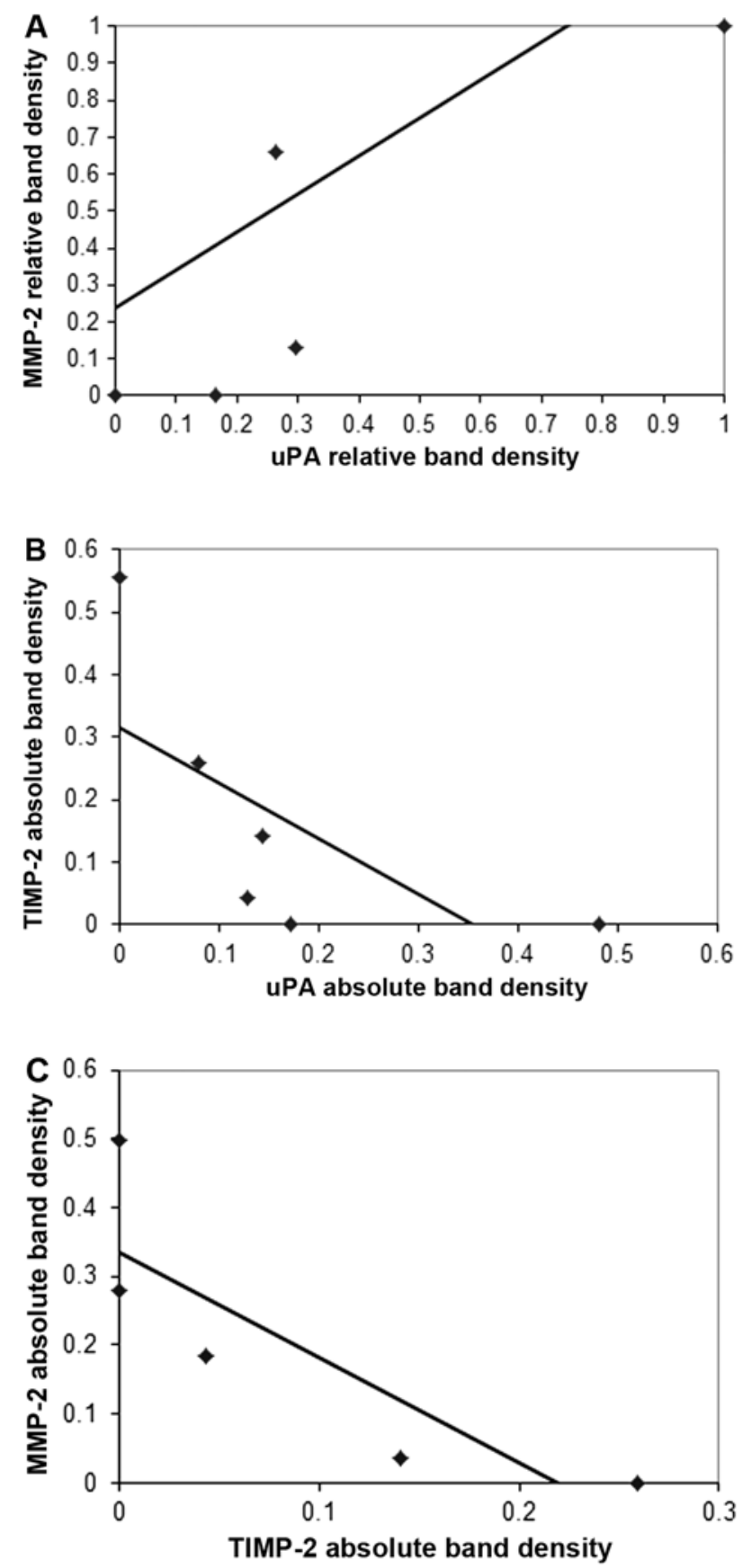

Figure 6. (A) Correlation between the effects of NM on glioma LN-18 uPA and MMP-2 expression (correlation coefficient $\mathrm{r}=0.504$ ). (B) Correlation between the effects of NM on glioma LN-18 MMP-2 and TIMP-2 expression (correlation coefficient $\mathrm{r}=-0.842$ ). (C) Correlation between the effects of $\mathrm{NM}$ on LN-18 uPA and TIMP-2 expression (correlation coefficient $r=-0.679$ ).

cancer prevention has been extensively documented (19). The nutrient mixture was formulated by selecting nutrients that act on critical physiological targets in cancer progression and metastasis, as documented in both clinical and experimental studies. Combining these micronutrients expands metabolic targets, maximizing biological impact with lower doses of components. A previous study of the comparative effects of NM, green tea extract and EGCG on inhibition of MMP-2 and MMP-9 secretion of different cancer cell lines with varying MMP secretion patterns, revealed the superior potency of NM over GTE and EGCG at equivalent doses (20). These results 
can be understood from the more comprehensive treatment offered by the combination of nutrients in NM over individual components of NM since MMP-2 and MMP-9 are mediated by differential pathways.

Optimal ECM structure depends upon adequate supplies of ascorbic acid and the amino acids lysine and proline to ensure proper synthesis and hydroxylation of collagen fibers. In addition, lysine contributes to ECM stability as a natural inhibitor of plasmin-induced proteolysis $(15,21)$. Manganese and copper are also essential for collagen formation. There is considerable documentation of the potency of green tea extract in modulating cancer cell growth, metastasis, angiogenesis and other aspects of cancer progression (22-28). N-acetyl cysteine and selenium have demonstrated inhibition of tumor cell MMP-9 and invasive activities, as well as migration of endothelial cells through ECM (29-31). Ascorbic acid demonstrates cytotoxic and antimetastatic actions on malignant cell lines (32-36) and cancer patients have been found to have low levels of ascorbic acid $(37,38)$. Low levels of arginine, a precursor of nitric oxide (NO), can limit the production of NO, which has been shown to predominantly act as an inducer of apoptosis (39).

In conclusion, the NM demonstrated potent anticancer activity by targeting primary mechanisms responsible for the aggressive spread of gliomas. In this in vitro study, the NM significantly inhibited secretion of uPA and MMP-2 and -9, and increased secretion of TIMP-2 in glioma LN-18 and T-98 cells, suggesting its potential in modulating cancer invasion and metastasis. Glioma A-172 cells did not secrete uPA; however, MMP-2 secretion by A-172 was inhibited by NM and secretion of TIMP-2 was enhanced by NM. NM inhibition of MMP-2 secretion was found to be correlated significantly with Matrigel invasion of glioma A-172 cell line. Furthermore, use of the nutrient mixture would not pose any toxic effect clinically, especially in the relevant doses, as in vivo safety studies demonstrate. A previous in vivo toxicology study (Roomi et al, J Am Coll Nutr 22: 77, abs. 86, 2003) showed that NM had no adverse effects on vital organs (heart, liver and kidney), or on the associated functional serum enzymes.

\section{Acknowledgements}

Mr. Monterrey provided assistance in scanning the gels. The research study was funded by Dr Rath Health Foundation (Santa Clara, CA, USA) a non-profit organization.

\section{References}

1. ACS: What are the key statistics about brain and spinal cord tumors? http://www.cancer.org/cancer/braincnstumorsin adults/detailedguide/brain-and-spinal-cord-tumors-in-adults-keystatistics. Last revised 2/6/13. Accessed 12/20/13.

2. ABTA (American Brain Tumor Association): Brain tumor facts http://www.abta.org/news/brain-tumor-fact-sheets/. Last revised $11 / 12$. Accessed 12/20/13

3. PAC2 (Parents Against Childhood Can Cancer) Cancer Facts and Statistics http://curechildhoodcancer.ning.com/page/ facts-1.

4. Yurchenko PD and Schitny JC: Molecular architecture of basement membranes. FASEB J 4: 1577-1590, 1990.

5. Barsky SH, Siegel GP, Jannotta F and Liotta LA: Loss of basement membrane components by invasive tumors but not by their benign counterparts. Lab Invest 49: 140-147, 1983

6. Liotta LA, Tryggvason K, Garbisa A, Hart I, Foltz CM and Shafie S: Metastatic potential correlates with enzymatic degradation of basement membrane collagen. Nature 284: 67-68, 1980
7. Nelson AR, Fingleton B, Rothenberg ML and Matrisian LM: Matrix metalloproteinases: biologic activity and clinical implications. J Clin Oncol 18: 1135-1149, 2000.

8. Stetler-Stevenson WG: The role of matrix metalloproteinases in tumor invasion, metastasis and angiogenesis. Surg Oncol Clin N Am 10: 383-392, 2001.

9. Stetler-Stevenson WG: Type IV collagenases in tumor invasion and metastasis. Cancer Metastasis Rev 9: 289-303, 1990.

10. Jäälinoiä J, Herva R, Korpela M, Höyhtyä M and TurpeenniemiHujanen T: Matrix metalloproteinase 2(MMP-2) immunoreactive protein is associated with poor grade and survival in brain neoplasms. J Neurooncol 46: 81-90, 2000.

11. Smith ER, Zurzkowski D, Saad A, Scott RM and Moses MA: Urinary biomarkers predict brain tumor presence and response to therapy. Clin Cancer Res 14: 2378-2386, 2008.

12. Dano K, Andreasen PA, Grondahl-Hansen J, Kristensen P, Nielsen LS and Skriver L: Plasminogen activators, tissue degradation and cancer. Adv Cancer Res 44: 139-266, 1985.

13. Duffy MJ, Duggan C, Mulcahy HE, McDermott EW and O'Higgins NJ: Urokinase plasminogen activator: a prognostic marker in breast cancer including patients with axillary nodenegative disease. Clin Chem 44: 1177-1183, 1998.

14. Bindal AK, Hammoud M, Shi WM, Wu SZ, Sawaya R and Rao JS: Prognostic significance of proteolytic enzymes in human brain tumors. J Neurooncol 22: 101-110, 1994.

15. Rath M and Pauling L: Plasmin-induced proteolysis and the role of apoprotein(a), lysine and synthetic analogs. Orthomolecular Med 7: 17-23, 1992.

16. Andreasen PA, Kjøller L, Christensen L and Duffy MJ: The urokinase-type plasminogen activator system in cancer metastasis: a review. Int J Cancer 72: 1-22, 1997.

17. Niedzwiecki A, Roomi MW, Kalinovsky $\mathrm{T}$ and Rath M: Micronutrient synergy - a new tool in effective control of metastasis and other key mechanisms of cancer. Cancer Metastasis Rev 29: 529-543, 2010.

18. Roomi MW, Monterrey JC, Kalinovsky T, Niedzwiecki A and Rath M: Inhibition of invasion and MMPs by a nutrient mixture in human cancer cell lines: a correlation study. Exp Oncol 32: 243-248, 2010.

19. Amin AR, Kucek O, Khuri FR and Shin DM: Perspectives for cancer prevention with natural compounds. J Clin Oncol 27: 2712-2725, 2009.

20. Roomi MW, Monterrey JC, Kalinovsky T, Rath $M$ and Niedzwiecki A: Comparative effects of EGCG, green tea and a nutrient mixture on the patterns of MMP-2 and MMP-9 expression in cancer cell lines. Oncol Rep 24: 747-757, 2010.

21. Sun Z, Chen YH, Wang P, Zhang J, Gurewich V, Zhang P and Liu JN: The blockage of high-affinity lysine binding sites of plasminogen by EACA significantly inhibits prourokinaseinduced plasminogen activation. Biochem Biophys Acta 1596: 182-192, 2002.

22. Kemberling JK, Hampton JA, Keck RW, Gomez MA and Selman SH: Inhibition of bladder tumor growth by the green tea derivative epigallocatechin-3-gallate. J Urol 170: 773-776, 2003.

23. Sato D and Matsushima M: Preventive effects of urinary bladder tumors induced by N-butyl-N-(4-hydroxybutyl)-nitrosamine in rat by green tea leaves. Int J Urol 10: 160-166, 2003.

24. Valcic S, Timmermann BN, Alberts DS, Wachter GA, Krutzsch M, Wymer J and Guillen JM: Inhibitory effect of six green tea catechins and caffeine on the growth of four selected human tumor cell lines. Anticancer Drugs 7: 461-468, 1996.

25. Mukhtar $\mathrm{H}$ and Ahmed N: Tea polyphenols: prevention of cancer and optimizing health. Am J Clin Nutr 71 (Suppl 6): S1698-S1702, 2000

26. Yang GY, Liao J, Kim K, Yurtow EJ and Yang CS: Inhibition of growth and induction of apoptosis in human cancer cell lines by tea polyphenols. Carcinogenesis 19: 611-616 1998.

27. Taniguchi S, Fujiki H, Kobayashi H, Go H, Miyado K, Sadano H and Shimikawa R: Effect of (-) epigallocatechin gallate, the main constituent of green tea, on lung metastasis with mouse B16 melanoma cell lines. Cancer Lett 65: 51-54, 1992.

28. Hara Y: Green Tea: Health Benefits and Applications. Marcel Dekker, Inc., Basel, New York, 2001.

29. Kawakami S, Kageyama Y, Fujii Y, Kihara K and Oshima H: Inhibitory effects of N-acetyl cysteine on invasion and MMP 9 production of T24 human bladder cancer cells. Anticancer Res 21: 213-219, 2001.

30. Morini M, Cai T, Aluigi MG, Noonan DM, Masiello L, De Floro S, D'Agostinin F, Albini A and Fassima G: The role of the thiol $\mathrm{N}$-acetyl cysteine in the prevention of tumor invasion and angiogenesis. Int J Biol Markers 14: 268-271, 1999. 
31. Yoon SO, Kim MM and Chung AS: Inhibitory effects of selenite on invasion of HT 1080 tumor cells. J Biol Chem 276 20085-20092, 2001

32. Naidu KA, Karl RC and Coppola D: Antiproliferative and proapoptotic effect of ascorbyl stearate in human pancreatic cancer cells: association with decreased expression of insulinlike growth factor 1 receptor. Dig Dis Sci 48: 230-237, 2003.

33. Maramag C, Menon M, Balaji KC, Reddy PG and Laxmanan S: Effect of vitamin $C$ on prostate cancer cells in vitro: effect on cell number, viability and DNA synthesis. Prostate 32: 188-195, 1997.

34. Koh WS, Lee SJ, Lee H, Park C, Park MH, Kim WS, Yoon SS, Park K, Hong SI, Chung MH and Park CH: Differential effects and transport kinetics of ascorbate derivatives in leukemic cell lines. Anticancer Res 8: 2487-2493, 1998.

35. Chen Q, Espey MG, Krishna MC, Mitchell JB, Corpe CP, Buettner GR, Shacter E and Levine M: Pharmacologic ascorbic acid concentrations selectively kill cancer cells: action as a pro-drug to deliver hydrogen peroxide to tissues. Proc Natl Acad Sci USA 102: 13604-13609, 2005.
36. Kurbacher CM, Wagner U, Kolster B, Andreotti PE, Krebs D and Bruckner HW: Ascorbic acid (vitamin C) improves the antineoplastic activity of doxorubicin, cisplatin and paclitaxel in human breast carcinoma cells in vitro. Cancer Lett 103: 183-189, 1996.

37. Núñez Martín C, Ortiz de Apodaca Y and Ruiz A: Ascorbic acid in the plasma and blood cells of women with breast cancer. The effect of consumption of food with an elevated content of this vitamin. Nutr Hosp 10: 368-372, 1995 (In Spanish).

38. Anthony HM and Schorah CJ: Severe hypovitaminosis C in lungcancer patients: the utilization of vitamin $C$ in surgical repair and lymphocyte-related host resistance. Br J Cancer 46: 354-367, 1982 .

39. Cooke JP and Dzau VJ: Nitric oxide synthase: role in the genesis of vascular disease. Annu Rev Med 48: 489-509, 1997. 